\title{
CLASS ROOMS, COURT ROOMS, WAR ROOMS, Cells: MADAM Justice LoUise ARBOUR, CANADA'S NEWEST COURT JUSTICE
}

Wayne Renke

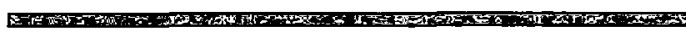

"Her record speaks for itself .... It's an outstanding appointment. She is a woman of brilliance, integrity - she is a woman who has dealt with some of the most difficult and challenging issues of our modern time:" The Honourable Anne McLellan.'
\end{abstract}

"It's a magnificent appointment .... She's just so highly regarded in this province. She's got expertise in criminal law, and we just think that's a wonderful appointment:" Alan Gold. ${ }^{2}$

"I hate to disappoint you ... but I haven't even heard anything negative about her:" Robert Martin. ${ }^{3}$

On June 10, 1999, the Honourable Anne McLellan, Minister of Justice and Attorney General of Canada, announced the appointment to the Supreme Court of Canada of Madam Justice Louise Arbour of the Ontario Court of Appeal, effective September 15, 1999. Judging a judge - as opposed to a judgment - is a difficult and somewhat presumptuous undertaking, especially when the judgment concerns not so much the judge that was, as the judge that will be. Yet giving some thought to what we can expect from the latest addition to the Supreme Court is natural and prudent, particularly given the recent rapid turnover of Supreme Court personnel, including the very recently announced resignation of

1 L. Eggertson, "Arbour quits U.N. to join Supreme Court" The Toronto Star (1 1 June 1999), online: The Toronto Star Online $<$ http://www.thestar.com/back issues.../news/990611NEW01b NA-COURTI1.html

2 J. Quinn, "Lawyers applaud Arbour's selection" The Toronto Star (11 June 11 1999), online: The Toronto Star Online $<$ http://www:thestar.com/back issues...11/news/99061 1 NEW07 NA-REAX11.html>.

3 K. Makin, "From Bench to Boșnia" Canadian Lawyer 20:8 (September, 1996) 18 at 20.

4 Department of Justice Canada, News Release: "Madam Justice Louise Arbour Appointed to the Supreme Court of Canada" (10 June, 1999), online: Department of Justice Canada Home Page $<$ http://canada.justice.gc.ca/News/Nominations/1999/int0610 en.html $>$.
Chief Justice Antonio Lamer. ${ }^{5}$ What kind of Supreme Court judge will Justice Arbour be? Elevation may effect transmutation, but some çlues may be gleaned from her curriculum vitae and from some of her work.

\section{LIFE $^{6}$}

Justice Arbour's eventually bilingual, bicultural life began in Montréal, Québec on February 10, 1947. Her early education was in a convent. She received a Bachelor of Arts degree in 1967, and an LL. L. from l'Université de Montréal in 1970. During law school, Chief Justice Lamer was one of her mentors. ${ }^{7}$ The young Justice Arbour became involved in Québec nationalist politics. Although she "always loved street politics,"she "spent more time playing poker and dancing in discotheques than being consumed by political discourse. We partied our way though law school until we were hit by the cold shower of the War Measures Act." ${ }^{\prime 8}$

5 K. Powell, "Supreme Court chief justice hangs up robe" The [Edmonton] Journal (22 August 1999) A1.

6 Most of the biographical materials have been assembled from the following sources: Canadian Who's Who (Toronto: University of Toronto Press, 1999) 30; Department of Justice Canada, News Release, supra note 4; Convocation Materials, Spring Convocation of Osgoode Hall Law School of York University, (17 May 1995); Makin, supra note 3; J. Geddes, "A star for the Supreme Court" Maclean's 112:25 (21 June 1999) 21; Minister of Justice and Attorney General (Canada) News Release: "Ontario Court of Appeal Appointment Announced" (16 February 1990), online: QL (JUDG); University of New Brunswick $170^{\text {th }}$ Encaeia, May 19 and 20, 1999, Highlights, online: University of New Brunswick Home Page <http://www.unb.ca/graduation/honorary:html>; W. Walker, "Arbour takes on job of a lifetime" The Toronto Star (11 June 1999), online: The Toronto Star Online $<$ http://www.thestar:com/back_issues.../news/ 990611NEW07NA-ARBOUR'11.html.

7 Lamer C.J.C., "Remarks of the Right Honourable Antonio Lamer, P.C., Chief Justice of Canada to the Council of the Canadian Bar Association" (Edmonton, Alberta, 21 August 1999), online: QL (LNET).

$8 \quad$ Makin, supra note 3 at 19. 
Justice Arbour articled with the Legal Department of the City of Montréal, and was admitted to the Québec bar in 1971. She clerked for Mr. Justice Louis-Phillipe Pigeon of the Supreme Court in 1971-1972. ${ }^{9}$ She subsequently completed graduate work at the University of Ottawa Faculty of Law (Civil Section).

Justice Arbour joined the Faculty of Osgoode Hall Law School of York University in 1974, and taught there until 1987. She received tenure and promotion to the rank of Associate Professor in 1977, the same year that she was admitted to the Ontario bar. She taught Criminal Law, Criminal Procedure, Evidence, and Civil Law, and served as Associate Dean of the Faculty. Her publications output was modest. In addition to some brief case annotations in the Criminal Reports (for which she served as Québec editor), ${ }^{10}$ she wrote four main articles." Her work was concise, scholarly, and wellresearched. It was doctrinal rather than theoretical. She and Larry Taman, her partner for many years, produced (by its publisher's account) Canada's first commercial casebook on criminal procedure - Criminal Procedure: Cases, Text and Material. ${ }^{12}$ The collection pushed no envelope.

Justice Arbour was Vice-President of the Canadian Civil Liberties Association in the 1980's, and with Alan Borovoy presented its brief to the Special Committee on Pornography and Prostitution. ${ }^{13}$ Additional preappointment activities included serving as a Research Officer for the Law Reform Commission of Canada (she was a colleague of Chief Justice Lamer), ${ }^{14}$ and as a

9 Justice Arbour is the first former Supreme Court law clerk to return to the Supreme Court as a judge: Lamer, supra note 7 at. 3.

10 See, for example, Justice Arbour's annotations to $R$. v. Charron' (1985), 46 C.R. (3d) 267 at 268 (Que. Ct. S.P.) [hereinafter the "Charron Annotation"]; R. v. Manuel (1986), 50 C.R. (3d) 47 (Que. Ct. S.P.); Chartrand v. Quebec (Minister of Justice) (1986), 55 C.R. (3d) 97 (Que. S.C.); Quebec (A.G.) v. Dubois (1987), 61 C.R. (3d) 159 (Que. C.A.).

i "Comparative Judicial Styles: The Development of the Law of Murder in the Quebec and Ontario Courts of Appeal" (1980), 11 R.D.U.S. 197; "Developments in Criminal Law and Procedure: the 1981-82 Term".(1983), 5 Supreme Court L. Rev. 167; "The Politics of Pornography: Towards an Expansive Theory of Constitutionally Protected Expression" in J. M. Weiler and R. M. Elliot eds., Litigating the Values of a Nation. The Canadian Charter of Rights and Freedoms (Toronto: Carswell, 1986) 294; and "Canadian Criminal Law: Bicultural Accomplishments and Tensions Before and After the Charter" (1987) Cambridge Lect 125. "The Oracle of the Criminal Code"' (1975) 13 Osgoode Hall L. J. 315 is a short contribution to a review symposium of Paul Weiler's In the Last Resort.

12 (Toronto: Emond-Montgomery, 1980). For, respectively, a critical and a luke-warm review, see S. A. Cohen (1980-81) 23 Crim. L. Q. 266 and J. F. Harris (1982-83) 12 Man. L.J. 253.

13 Weiler and Elliot, supra note 1.1 at iii ("Contributors List").

${ }_{14}$ Lamer, supra note 7 at 3.
Member of the Canadian Law Information Council Advisory Committee to Reference Centre for French Language Common Law Documentation. She was also a member of the editorial boards of the Osgoode Hall Law Journal and La Revue Général de Droit of the University of Ottawa.

In 1987, Justice Arbour was appointed to the Supreme Court of Ontario (High Court of Justice). In 1990, she was elevated to the Ontario Court of Appeal.

In 1995, she was appointed under the Inquiries Act (Canada) as Commissioner "to investigate and report on the state and management of that part of the business of the Correctional Service of Canada that pertains to the incidents that occurred at the Prison for Women in Kingston, Ontario, beginning on April 22, 1994 and on the responses of the Correctional Service of Canada thereto . ..." Her Kingston Report is impressive on many levels. The process she adopted was commendable. To familiarize herself with prison issues, Justice Arbour visited women's prisons across Canada; met with administrators, front-line workers, and federallysentenced women; consulted with academics; and utilized the University of Toronto's Centre of Criminology Library to track down scholarly work. In addition to the traditional inquiry techniques of investigations, interviews, and hearings, the policy consultation phase of the inquiry relied on Roundtable discussions. ${ }^{16}$ The Kingston Report is sound in principle: "[a] guilty verdict followed by a custodial sentence is not a grant of authority for the State to disregard the very values that the law, particularly criminal law, seeks to uphold and to vindicate, such as honesty, respect for the physical safety of others, respect for privacy and for human dignity." 17 Her recommendations were wideranging and sensible - concerning issues such as crossgender staffing, the use of force and emergency response teams, the availability and use of healing lodges for aboriginal women, limitations on the use of administrative segregation, improving the accountability of correctional services, improving the prisoner complaints and grievances system, and the creation of institutions and rules appropriate to the realities of women's imprisonment. ${ }^{18}$

15 Order in Council PC 1995-698, April 10, 1995, reproduced in the Report of the Commission of Inquiry into Certain Events at the Prison for Women in Kingston (Ottawa: Public Works and Government Services Canada, 1996) viii - $x$ [hereinafter the Kingston Report].

16 Ibid. at xvii.

17 Ibid. at xi.

18 lbid. at $251-259$. 
In August, 1996, the United Nations' Security Council appointed Justice Arbour Chief Prosecutor of the International Tribunal for the Prosecution of Persons Responsible for Serious Violations of International Humanitarian Law Committed in the Territory of the Former Yugoslavia and of the International Tribunal for Rwanda [the "War Crimes Tribunal"].

Justice Arbour has received numerous awards and distinctions, including honorary degrees from Osgoode Hall Law School and the University of New Brunswick in Fredericton; the University Medal of l'Université de Montréal; the G. Arthur Martin Award, awarded by the Criminal Lawyers Association (Ontario); ${ }^{19}$ and the 1999 Louise Weiss Foundation prize. ${ }^{20}$

Justice Arbour has three children.

\section{WORK $^{21}$}

To gauge a judge's trajectory, we should consider not only experience but also his or her work product or record. As a global comment on her record, I think it fair to observe that none of Justice Arbour's judgments or publications represent a legal "breakthrough;" she has not reconceptualized any area of law; she has not shifted any paradigms. But what we do see in her work is an intelligent, thorough, sincere, sympathetic attempt to apply the law in particular cases.

Her record discloses three main dispositions: an acceptance of the pre-eminence of the rule of law and a correlative willingness to criticize state initiatives and actions; an acceptance of the importance of all of the interests protected by the Canadian Charter of Rights and Freedoms ${ }^{22}$ and a leavening of modesty about what the law, by itself, can accomplish.

\section{The Rule of Law}

Justice Arbour has demonstrated in word and action a commitment to the "rule of law", in the sense of governance of social activities according to valid legal

19 Criminal Lawyers Association Newsletter 20:1 (17 May 1999) 25.

20 Bench and Bar Daily News Digest, Vol. IX - Issue 120, citing Ottawa Le Droit 20 22/6 (23 June 1999), online: QL (BBDN). "Previous winners of the prize include Médecins sans Frontièrs, Helmut Schmidt and Anwar El Sadat:" ibid.

21 My review is necessarily highly selective. A "judges' field" search of Quick Law's Canadian Judgments database yielded 1020 judgment "hits," indicating judgments which she authored or participated in.

22 Canadian Charter of Rights and Freedoms, Part I of the Constitution Act, 1982, being Schedule B to the Canada Act 1982 (U.K.), 1982, c. 11 [hereinafter the Charter]. norms, as opposed to arbitrary actions of the powerful. A commitment to the rule of law is more a duty than a virtue for a judge; but Justice Arbour has displayed tenacity, initiative, and courage in applying that rule to the powerful.

Justice Arbour's work as Prosecutor for the War Crimes Tribunal has been, through and through, an effort to bring the rule of law to bear on the lawless acts of lawless men. She submitted and received confirmation for an indictment charging, inter alios, Slobodan Milosevic, the President of the Federal Republic of Yugoslavia, with crimes against humanity - murder, deportations, and persecutions - and with violations of the laws and customs of war. ${ }^{23}$ Michael Ignatieff has described Justice Arbour's action as a "watershed in the history of international law - the first indictment of an incumbent head of state." ${ }^{24}$ Justice Arbour had to overcome some significant international pressure, particularly from American elements, to go forward with the indictment. She demonstrated a profound understanding of responsibility. As Michael Ignatieff has observed, "guilt means nothing unless a crime can be traced back to a single individual. That is why justice is about the naming of names. ${ }^{25}$ She has proven herself capable of marching up the chain of command and assigning responsibility to the powerful.

The Kingston Report exposed the breakdown in the rule of law at the Prison for Women. She denounced the failure of prison officials to respect constitutional rights, legislated rules, or even their own correctional policies. ${ }^{26}$ Although she generally refrained from attributing personal responsibility in the Kingston Report, ${ }^{27}$ she did hold CSC Commissioner John Edwards to account in several instances. ${ }^{28}$ He subsequently resigned.

Like many other judges in the Charter era, she has held Parliament, legislatures, and, thereby, democratic majorities accountable to the standard of the rule of law,

23 Justice Louise Arbour, Press Release, JL/PIU/404 -E, "Statement by Justice Louise Arbour, Prosecutor ICTY" (27 May 1999), online: International Criminal Tribunal for the Former Yugoslavia Homepage <http://www.un.org/icty/ pressrel/p404-e.htm>; and International Criminal Tribunal for the Former Yugoslavia, Press Release, JL/PIU/403 E,"President Milosevic and Four Other Senior FRY Officials Indicted for Murder, Persecution and Deportation in Kosovo" (27 May 1999), ibid. at p403-e.htm.

24 M. Ignatieff, “Arbour's Wake-Up Call” Time (31 May 1999), online: Time Magazine International $<$ http://www.pathfinder.com/time/magazine/articles/intl/0,32 $66,27031,00$ html $>$.

25 Ibid.

${ }^{26}$ Kingston Report, supra note 15 at 179.

27 lbid. at xiii.

28 For example, ibid: at 173. 
striking down legislation that violates constitutional norms. Such decisions are hardly remarkable. Somewhat more remarkable was Justice Arbour's constitutional review of school legislation in the Eaton case - in the absence of statutorily required notice to the Attorneys General. ${ }^{29}$ A tribunal constituted under the Ontario Education Act confirmed that a child with certain disabilities should be moved from a neighbourhood school to a "special education class." Justice Arbour found that the Act discriminated against the child on the basis of disability, without justification under section 1 of the Charter. She declared that the Act must be "read up" to include a direction that, unless the parents of a disabled child consent to the placement of that child in a segregated environment, the child must have a placement that is the least exclusionary from the mainstream, that is reasonably capable of meeting the child's needs. ${ }^{30}$ In the course of allowing the appeal from her judgment on the grounds that the Tribunal's decision imposed no burden or disadvantage, Sopinka J. criticized Justice Arbour for embarking on a constitutional review without due notice to the governmental authorities. ${ }^{31}$ Justice Arbour's pursuit of justice was perhaps too enthusiastic.

Yet another example of enthusiasm occurred in the Leroux case, ${ }^{32}$ in which Justice Arbour put the rule of law ahead of stare decisis. The case turned on whether restricting the term "spouse" in the Ontario Insurance Act and Standard Automobile Policy to only legally married persons would deny common law spouses equal protection and benefit of the law and amount to discrimination on an "analogous ground" under section 15(1) of the Charter. Justice Arbour - then of the Ontario High Court of Justice - en route to expanding the denotation of the term "spouse" to include common law spouses (a result dictated, in her view, by section 15 of the Charter), declined to follow an Ontario Court of Appeal decision. On the appeal, the Court of Appeal chided Justice Arbour. She was not free to follow her own Charter lights, but should have abided by binding authority. It was for the Court of Appeal to modify its earlier ruling, not a lower court judge, and it was not prepared to find an infringement of section 15(1) in this case. Leroux was not further appealed, but a companion case was. Justice Arbour's conclusions were vindicated by the Supreme Court in Miron v. Trudel. ${ }^{33}$ The majority

29 Eaton v. Brant County Board of Education (1995), 22 O.R. (3d) I (C.A.), rev'd [1997] I S.C.R. 241 [hereinafter Eaton].

30 Ibid. at 21 (C.A.).

31 Ibid. (S.C.C.) at 265.

32 Leroux v. Co-operators General Insurance (1991), 4 O.R. (3d) 609 (C.A.) [hereinafter Leroux].

33 Miron v. Trudel (1995), 124 D.L.R. (4 $\left.4^{\text {th }}\right) 693$ (S.C.C.). See R. E. Somerleigh (counsel for the plaintiff Leroux), Letter to the Editor, Canadian Lawyer 21:1 (January 1997) 5 for some of the Supreme Court held that the exclusion of common law spouses from coverage was discriminatory, and read appropriate inclusionary language into the benefit provisions.

In the Barrett case, ${ }^{34}$ Justice Arbour attempted to hold trial judges to the rule of law, by requiring reasons in cases involving evidential gaps or conflicting testimony on important issues. Reasons give appellate courts a better foundation for assessing the reasonableness of judicial fact-finding. Her sound approach has been largely rejected by the Supreme Court, on appeal from Barrett and in other cases. ${ }^{35}$

Justice Arbour has criticized police lawlessness and abuses. She added her voice in Barrett to a chorus of criticism of the evidential procedures of the Toronto police hold-up squad. She recommended that the police videotape interviews with accuseds. In her opinion, videotape evidence "proves immensely superior to the recollection of . . . witnesses, even of those who took notes, as an evidentiary tool." 36 She recommended that officers at an interview take contemporaneous, independent notes. ${ }^{37}$ Videotaping and proper note-taking discourages the invidious practice of intentionally leaving accuseds without independent evidence of alleged police misconduct. Justice Arbour emphasized that where the voluntariness of an accused's confession is in issue, the Crown must prove the voluntariness beyond a reasonable doubt and that evidential gaps caused by failing to videotape interviews or to keep proper notes may preclude the satisfaction of this burden of proof.

Acceptance of the Importance of All CharterProtected Interests

A key feature of Justice Arbour's decisions is an acceptance of the importance of all of the interests protected by the Charter. This broad commitment distinguishes her from the wide variety of advocates who emphasize or prioritize certain Charter rights, at the expense of others. Positions like Justice Arbour's require the balancing of relevant interests in particular circumstances. A balancing approach makes abstract predictions of results difficult.

illuminating comments on the Leroux appeal.

$34 R$. v. Barrett (1993), 82 C.C.C. (3d) 266 (Ont. C.A.), rev'd (1995) 96 C.C.C. (3d) 319 (S.C.C.) [hereinafter Barrett].

35 R. v. Burns (1994), 89 C.C.C. (3d) 193 (S.C.C.).

36 Barrett, supra note 34 at 275 . The Supreme Court did not comment on these matters.

37 Ibid. 
Three sets of overlapping interests protected by the Charter are especially relevant to Justice Arbour: (a) individual liberty; (b) state institutions necessary for an ordered democratic society; and (c) the interests of vulnerable groups.

\section{(a) Individuals, Liberty, and the State}

Justice Arbour has defended individual liberty from state interference through her opposition to censorship and her protection of the rights of suspects and accuseds.

In an early article, Justice Arbour argued that pornography is constitutionally-protected expression. ${ }^{38}$ She accepted that pornography is political and discriminatory. Nonetheless, she rejected attempts to censor pornography through the Criminal Code ${ }^{39}$ She would countenance censorship, as a reasonable limit on expression in a free and democratic society, only if pornography could be shown to constitute a "clear and present danger" to the welfare of women. In her view, the evidence did not safely permit such a conclusion. ${ }^{40}$ Justice Arbour responded to censorship advocates such as Catharine MacKinnon with the counterclaim that state censorship is the true threat requiring minimization: "When feminists argue that pornography "chills women's expression,' they should not forget the very real chill of censorship and how it has attempted to silence them in the past." "Injunctions chill. expression," she wrote; "to say that pornography silences women is merely a figure of speech in comparison. Women can be silenced much more effectively by law makers than pornographers." ${ }^{.42}$

Justice Arbour comes closest to defence counsel advocacy in her decisions concerning the rights of suspects and accuseds. She has observed in the criminal law the key conflict between the coercive power of the state, which must be monitored and controlled, and the liberty of the accused individual:

Criminal law . . . is a body of law that is coercive, authoritarian, and, yet, in a sense,

38 "The Politics of Pornography: Towards an Expansive Theory of Constitutionally Protected Expression" in Weiler and Elliot, supra note 11 at 294.

39 R.S.C. 1985 , c. C-46 [hereinafter the Criminal Code].

40 Supra note 38 at 298.

41 Ibid. at 304 [footnote omitted]

42 Ibid. Along the way to upholding the Criminal Code's obscenity provisions, the Supreme Court dealt with the difficulties of proof of social harm. It did not adhere to Justice Arbour's high liberal standard of "clear and present danger," but a lesser, more socially-protective standard of "rational link" or "rational connection" between obscenity and harm: $\dot{R}$. v. Butler, [1992] I S.C.R. 452, Sopinka J. at 501 - 502. ironically, highly suspicious of state power, particularly of state abuse of power .... [A] fundamental assumption [of the criminal law] $\ldots$ is that the prosecution must be kept under a very strict regime of checks and balances, because it has behind it the might of the state, and, that the accused must be given instruments to resist the possible abuses that come from the state power backing up the prosecution. ${ }^{43}$

In keeping with this orientation, Justice Arbour has protected suspects from unreasonable search and seizure, defended accuseds' rights to make full answer and defence, shielded accuseds from improper evidence, and upheld the presumption of innocence against legislative incursion. As will be seen, however, she is not simply defence counsel in other robes.

\section{(i) search and seizure}

In Johnson v. Minister of Revenue for the Province of Ontario, ${ }^{44}$ an accused challenged section 15(3) of Ontario's Tobacco Tax $\mathrm{Act}^{45}$, which permitted any authorized person to stop and search any commercial vehicle in Ontario and to seize anything that may be evidence of a violation of that Act, all without reasonable and probable grounds. Justice Arbour characterized the legislation as "regulatory." She held quite properly - that persons have constitutionallyprotected privacy interests in commercial vehicles and their various cargos and contents, and that section 15(3) permitted serious intrusions on those interests. She acknowledged the line of Supreme Court cases upholding the constitutionality of random vehicle stops, but distinguished the Tobacco Tax Act circumstances. Tax collection is not an objective as pressing and substantial as preventing highway carnage. Furthermore, the subsection dictated more than (e.g.) the production of a driver's licence or insurance certificate - it authorized extensive search and seizure. Finally, the subsection had an overly broad effect. It applied to any commercial vehicle, regardless of whether grounds existed for the belief that the vehicle was connected with the tobacco trade. The government did not attempt to support the subsection under section 1 of the Charter. Justice Arbour struck it and a connected subsection down. ${ }^{46}$

43 "Remarks of the Honourable Louise Arbour upon Receiving the G. Arthur Martin Criminal Justice Award" Criminal Lawyers Association Newsletter, supra note 19 at 27.

44 (1990), 75 O.R. (2d) 558 (C.A.) [hereinafter Johnson v. M.N.R.].

45 R.S.O. 1980 , c. 502.

46 Had the search and seizure provisions contained a reasonable and probable grounds requirement, she would have supported the constitutionality of the subsection: Johnson v. M.N.R., supra note 44 at 574 . 
Justice Arbour also demonstrated a willingness to find police conduct in violation of section 8 of the Charter, although - by way of balancing - she ultimately supported the admissibility of the illegally-gathered evidence under section 24(2). In Mercer, ${ }^{47}$ the accuseds were registered hotel guests. A chambermaid entered their room (despite a duly posted "do not disturb" sign), and, in the course of her explorations and rummaging, found a pillowcase containing money. She notified the manager (who had suspected all along that the accused were up to no good). The manager entered the room, viewed the money, and also found a "brown, waxy brick." The manager called the police. On arrival, the police entered the room with the manager but sans warrant. The accuseds were subsequently charged with possession of a narcotic for the purposes of trafficking. The accused, Justice Arbour ruled, had a reasonable expectation of privacy in the hotel room. The fact that cleaning staff may enter a room does not eliminate this expectation - although Justice Arbour imported a sort of "plain view" exception: "[o]bjects not left in plain view or stored in areas which do not require daily maintenance, such as inside drawers, closets, toiletry bags, briefcases and suitcases, can be reasonably expected to remain private despite access to the room by hotel staff for cleaning purposes." ${ }^{.48}$ She held that the consent of the hotel manager did not constitute a waiver of the accused's section 8 rights or transform the police officers' search into a consent search. Despite finding that the accuseds' section 8 rights had been violated, Justice Arbour did not exclude the evidence: it was not conscriptive; the police officers made a good faith mistake of law in relying on the manager's purported authority; the evidence was important to the proof of guilt of the accuseds and its exclusion would work greater damage to the administration of justice than its admission.

\section{(ii) full answer and defence}

The Charron case $^{49}$ concerned a preliminary inquiry on a charge of first degree murder. Defence counsel sought to cross-examine a crown witness respecting crimes the witness may have committed to lay a foundation for impugning the witness' credibility. Dutil J.S.P. sustained the Crown's objection that credibility is irrelevant to a preliminary inquiry and the questioning was improper. In the Charron Annotation, Justice Arbour conceded that Dutil J.S.P.'s decision was consistent with certain Supreme Court authority. However, she pointed out that separating credibility and

\footnotetext{
47 R. v. Mercer (1992), 7 O.R. (3d) 9 (C.A.), leave to appeal ref'd [1992] 2 S.C.R. viii (sub nom. R. v. Kenny).

48. Ibid. at 15 . It is constitutionally prudent to clean up.

49 Supra note 10.
}

other facts in issue is difficult. Justices should not be quick to block cross-examination simply because it appears to be relevant to credibility. She conceded that the primary function of preliminary inquiries must be to determine whether there is sufficient evidence to commit the accused for trial, but argued that a secondary function is to provide discovery of the Crown's case to the defence. The defence should be entitled to collect foundational evidence at the preliminary inquiry, for use at trial..$^{50}$ Justice Arbour's responses rested on her appreciation of the rights of accuseds to make full answer and defence and the need for broad rights of cross-examination. She referred to the "nearly untouchable character of the right to cross-examine, which goes to the very foundations of the adversary system."

Consistent with her views on full answer and defence, Justice Arbour tackled the Seaboyer case ${ }^{52}$ as counsel (with Daniel MacDonald) before the Ontario Court of Appeal on behalf of the intervener the Canadian Civil Liberties Association. Seaboyer concerned Criminal Code restrictions on accuseds' abilities to adduce evidence (through cross-examination or otherwise) of complainants' sexual activity with any person other than the accused. The Association supported the accused in arguing that the restrictions offended sections 7 and 11(d) of the Charter, the conclusion ultimately arrived at by the Supreme Court. ${ }^{53}$

Justice Arbour's approach to full answer and defence is balanced. She recognizes that female victims of sexual offences have privacy rights that must be protected: "We are continuing to advocate that it is absolutely critical that we shelter sexual assault victims from intense and futile scrutiny into their medical

so Charron Annotation, supra note 10. Justice Arbour's approach has been followed in subsequent cases: $R$. v. George (1991), 69 C.C.C. (3d) 148 (Ont. C.A.); R. v. Giles (1992), 75 C.C.C. (3d) 315 (B.C.S.C.); R. v. Dawson (1998), 123 C.C.C. (3d) 385 (Ont. C.A.); R. v. Garofoli, [1990] 2 S.C.R. 1421; R. v. Alibhai (1998), 123 C.C.C. (3d) 556 (Ont. Ct. (Gen. Div.)). For the view that discovery has eclipsed the proper purpose of preliminary inquiries and rendered them unmanageable, see $R$. v. $O^{\prime}$ Connor, [1995] 4 S.C.R. 411, per L'Heureux-Dubé J. at 509.

s) Charron Annotation, supra note 10 at 269. She also pointed out that preventing cross-examination on credibility would undermine the availability of s. 715 of the Criminal Code, which allows evidence taken at preliminary inquiries to be read into evidence if, inter alia, the accused had "full opportunity to cross-examine the witness."

52 Re Seaboyer and the Queen (1987), 37 C.C.C. (3d) 53 (Ont C.A.), rev'd (1991), 66 C.C.C. (3d) 321 (S.C.C.) [hereinafter Seaboyer].

53 Ibid: at 395, 398 (S.C.C.). 
records." ${ }^{54}$ For her, the issue is (as it properly should be) the degree of probative value of the evidence, weighed against the prejudicial effect of the violation of a complainant's privacy:

We are going to take very vigorously the position that the court must scrutinize the probative value of that kind of [medical history] evidence with respect to the credibility of the witness. For instance, if the medical evidence discloses severe instances of completely repressed memory or profound amnesia, you could say that this might have some significance. Our position will be that the fact that someone is traumatized - after being tortured, for instance - is not necessarily grounds to suggest that his or her identification of the perpetrator or recollection of what happened is not reliable. 55

\section{(iii) evidence - similar fact}

One of the most dangerous species of evidence for an accused is similar fact evidence. Such evidence puts past bad acts of the accused before the trier of fact, with all of the attendant potential prejudice. Similar fact issues are frequently troublesome for accuseds in sexual offence cases. They may face allegations of multiple alleged offences against a single complainant, against multiple complainants, or against the complainant and other witnesses; multiple allegations may form separate counts against the accused in one trial.

Justice Arbour confronted the similar fact problem in Huot ${ }^{56}$ The accused was charged with a number of counts of sexual offences against two complainants. The alleged acts occurred over 30 years before trial. The trial judge considered the evidence respecting each count to be admissible respecting the others. Justice Arbour disagreed. The trial judge correctly stated the applicable principles drawn from C.R.B., ${ }^{57}$ but misapplied them. Very generally, similar fact evidence is admissible only if it tends to establish some relevant matter other than merely bad character or propensity and if its probative value outweighs its prejudicial effect. According to Justice Arbour, the evidence in question tended to establish only the accused's propensity to commit

54 J. Llewellyn and S. Raponi, "The Protection of Human Rights Through International Criminal Law: A Conversation with Madam Justice Louise Arbour, Chief Prosecutor for the International Criminal Tribunals for the Former Yugoslavia and Rwanda" (1999) 57 U. T. Fac. L. Rev. 83 at 92.

55 lbid.

s6 R.v. Huot (1993), 16 O.R. (3d) 214 (Ont. C.A.), aff'd [1994] 3 S.C.R. 827 [hereinafter Huot]

57 R. v. C.R.B. (1990), 55 C.C.C. (3d) । (S.C.C.). homosexual acts with adolescents. Numerous dissimilarities existed between the acts alleged by the two complainants. The evidence disclosed no plan or system and did not show the improbability of the complainants' separate allegations resulting from chance or coincidence. By resisting admissibility, Justice Arbour, if only by way of illustration, pushed the admissibility bar back up. It had sagged too low in Justice McLachlin's majority judgment in C.R.B., which had allowed significantly dissimilar evidence to be admitted under the similar fact rules. Justice Arbour rejected the Crown's argument that the evidence was admissible to "corroborate" the complainants' accounts, i.e., because it bolstered their credibility - an argument wrongly accepted by McLachlin J. in her C.R.B. majority. ${ }^{58}$ Justice Arbour found that the prejudicial effect of the evidence was great. Not only was the evidence tainted by the repugnancy of the acts alleged, but "one cannot ignore the special prejudice resulting from the passage of time." the fact that these allegations go back more than 30 years, the prejudicial effect of cumulating these allegations each serving as evidence for the other, seems to me to be insurmountable." ${ }^{\prime 60}$ Defending oneself is difficult enough when allegations are fresh; defence may be even more difficult when the evidence relates to events alleged to have taken place decades ago. Nonetheless, in all of the circumstances of the case, Justice Arbour found that the trial judge's error occasioned no substantial wrong or miscarriage of justice, so she dismissed the appeal. She did comment that had the error occurred in a jury charge, it would have been fatal. In excessively short reasons, the Supreme Court dismissed the appeal. The majority declined to consider the similar fact issue. ${ }^{61}$

\section{(iv) the presumption of innocence}

Justice Arbour dealt with legislation limiting the presumption of innocence in the Fisher case. ${ }^{62}$ Paragraph 121(1)(c) of the Criminal Code prohibited a government employee from taking a gift from a person dealing with the government, "unless he has the consent in writing of the head of the branch of government that employs him or of which he is an official, the proof of which lies on him." Justice Arbour, properly and without much ado,

58 Ibid. at $27-28$. Sopinka J. identified the error in his minority judgment: ibid. at $13 \cdot 14$.

59 Huot, supra note 56 at 220 (C.A.).

60 Ibid.

61 Ibid. at 829 (S.C.C.), Sopinka J., joined by La Forest, Cory, McLachlin, and Iacobucci JJ. In an even shorter separate concurring judgment, Gonthier J., joined by L'Heureux-Dubé J., found no error by the trial judge.

62 R. v. Fisher (1994), 17 O.R. (3d) 295 (Ont. C.A.), leave to appeal ref'd [1995] 1 S.C.R. x. 
rejected an argument that the provision was void for vagueness because of its lack of an express reference to a fault requirement: "As presently drafted, many Criminal Code provisions do not refer explicitly to any or all of the requisite fault elements. The courts, applying established common law principles to the language used by Parliament, must determine appropriate fault requirements." ${ }^{33}$ She also rejected an overbreadth argument. The provision, as interpreted by the courts, gives adequate guidance to the persons whose behaviour it regulates and limits law enforcement discretion. She then turned to the presumption of innocence. She found, again properly, that the provision imposed on an accused a burden of proving, on a balance of probabilities, that he or she had written consent to receive a gift; and that this imposition allowed for conviction despite the presence of reasonable doubts about guilt. The provision limited an accused's constitutional right to be presumed innocent.

Justice Arbour rejected the Crown's attempt to support the provision under section 1 of the Charter. She doubted whether the provision promoted an objective that warranted limiting constitutional rights. Regardless, the imposition of a persuasive burden on the accused was not reasonably necessary. An "evidential" burden (the burden of adducing some evidence) might have been imposed on the accused; or the burden could have been left on the Crown. Her remedy was to declare the words "the proof of which lies on him" to be of no legal effect, but otherwise to preserve the provision.

\section{(b) Supporting State Institutions}

As we have seen, Justice Arbour has been prepared to make decisions that support the criminal justice apparatus, in the right circumstances.

As a further example of Justice Arbour's support for state institutions, she did not translate her Huot recognition of the dangers of the passage of time into an automatic assumption of prejudice against accuseds. In the Bennett case, ${ }^{64}$ she anticipated the Supreme Court's clarification of $A s k o v^{65}$ in the Morin decision. ${ }^{66}$ She held that Askov did not establish an eight month time limitation for bringing a matter to trial. She emphasized that a stay based on a violation of an accused's section 11(b) right to trial within a reasonable time would only be granted following a careful balancing of the length of the delay, the explanation for the delay, any waiver by

63 Ibid. at 300 (C.A.).

64 R. v. Bennett (1991), 3 O.R. (3d) 193 (Ont. C.A.), aff'd (1992), 9 O.R. (3d) 276 (S.C.C.) [hereinafter Bennett].

$65 R$. v. Askov et al. (1990), 59 C.C.C. (3d) 449 (S.C.C.).

66 R. Morin (1992), 71 C.C.C. (3d) 1. the accused, and any prejudice to the accused arising from the delay demonstrated by the evidence. She rejected the argument that a $131 / 2$ month delay by itself violated the accused's right to be tried within a reasonable time. She pointed out the need for relevant comparable evidence in assessing whether a particular local jurisdiction's delays are unreasonable, and rejected the notion of an abstract cross-jurisdictional temporal standard of reasonableness. ${ }^{67}$

Justice Arbour has also interpreted accuseds' "substantive due process" rights favourably to the state. She has rejected defence arguments that would have made establishing actus reus and fault difficult in homicide prosecutions.

Her Cribben decision ${ }^{68}$ resolved two causation issues. First, Harbottle $e^{69}$ had established an elevated test for causal responsibility for first degree murder offences: the accused must be found, beyond a reasonable doubt, to have been a "substantial" (or integral or active) cause of the victim's death. There had been speculation that the Harbottle approach would be adopted for other homicide offences. Justice Arbour blocked that development. The test for causal responsibility for homicide offences other than first degree murder remains the Smithers test: the accused must be found beyond a reasonable doubt to have been "a contributing cause of death, outside the de minimis range." Second, Justice Arbour held that the Smithers test is constitutional. It is not void for vagueness. Neither does it violate constitutional fault requirements. Justice Arbour recognized the basic principle that the morally innocent should not be held criminally liable. The Smithers test does not impose a standard of causal responsibility so low that it sweeps the morally innocent into liability. Even if the accused is a legal cause of some prohibited consequence, if the accused is not shown to have had the constitutionally requisite fault, he or she cannot be convicted. The fault rules, then, impose the limits that prevent the Smithers causation rule from casting the net of liability too widely.

Justice Arbour visited the constitutional fault standards in the Durham case, ${ }^{71}$ which concerned the offence of careless use of a firearm under section 86(2) of the Criminal Code. The offence employed "without lawful excuse" language and required proof only of negligence for conviction. The issue was whether this level of fault was constitutionally sufficient, or whether

67 Bennett, supra note 64 at 215 (C.A.).

68 R. v. Cribben (1994), 17 O.R. (3d) 548 (Ont. C.A.)

69 R. v. Harbottle (1993), 84 C.C.C. (3d) 1 (S.C.C.), Cory J.

70 Smithers v. The Queen, [1978] I S.C.R. 506 per Dickson J. at 519 [hereinafter Smithers].

7 R. v. Durham (1992), 10 O.R. (3d) 596 (Ont. C.A.). 
proof of subjective awareness of risk was required. Justice Arbour held that the offence was a "regulatory offence" and not a true crime: Furthermore, the stigma attached to conviction was not sufficiently severe to require proof of subjective fault. She upheld the offence. In Finlay, ${ }^{72}$ the Supreme Court agreed. Without employing Justice Arbour's distinction between regulatory offences and true crimes, Lamer C.J.C., writing for the court on these points, held that objective liability is (generally) a constitutionally sufficient minimum fault requirement for an offence punishable by imprisonment. He expressly accepted and quoted Justice Arbour's opinion that the stigma attaching to conviction for a section $86(2)$ offence was not sufficient to draw the offence out of the general rule and to require proof of a subjective mental element. ${ }^{73}$

\section{(c) Protecting the Vulnerable}

Law may put people at risk not merely because of their alleged actions or inactions, but because of traits they share with a class or group of people singled out by the law. Justice Arbour has protected members of targeted and vulnerable groups, as we saw in the Eaton and Leroux cases.

Justice Arbour's arguments respecting the censorship of pornography and her advocacy in the Seaboyer case put her at odds with at least some women's rights advocates. She has taken steps, however, to protect women - witness her position on accuseds' access to complainants' medical records. One of her foremost efforts has been to ensure that sexual violence against women is not minimized or officially ignored. As leader of the War Crimes Tribunal prosecutorial team, Justice Arbour has pressed for a broad approach to sexual offences, conceived as offences of violence and as being acts of genocide, crimes against humanity, torture and persecution, and war crimes. (Her stance may presage a broad approach to sexual offences under domestic criminal law.) Her approach to sexual offences finds expression in the Akayesu case. ${ }^{74}$ The Akayesu Tribunal (Judges Laïty Kama (Presiding), Lennart Aspegren, and Navanethem Pillay) described rape as follows:

The Tribunal considers that rape is a form of aggression and that the central elements of the crime of rape cannot be captured in a mechanical description of objects and body parts . . . . Like torture, rape is used for such purposes as intimidation, degradation,

72 R. v. Finlay, [1993] 3 S.C.R. 103 [hereinafter Finlay].

73 Jbid. at 119.

74 Llewellyn and Raponi, supra note 54 at 90. humiliation, discrimination, punishment, control or destruction of a person. Like torture, rape is a violation of personal dignity, and rape in fact constitutes torture when it is inflicted by or at the instigation of or with the consent or acquiescence of a public official or other person acting in an official capacity.

The Tribunal defines rape as a physical invasion of a sexual nature, committed on a person under circumstances which are coercive. The Tribunal considers sexual violence, which includes rape, as any act of a sexual nature which is committed on a person under circumstances which are coercive. Sexual violence is not limited to physical invasion of the human body and may include acts which do not involve penetration or even physical contact ... . The Tribunal notes in this context that coercive circumstances, need not be evidenced by a show of physical force. Threats, intimidation, extortion and other forms of duress which prey on fear or desperation may constitute coercion, and coercion may be inherent in certain circumstances ... ${ }^{75}$

The Kingston Report is located at the intersection of women's rights and prisoners' rights. Its main concerns are with the treatment of female prisoners, in relation to the specific incident involving the deployment of the male emergency response team, strip searches, and subsequent violations of law and policy; broader issues of institutional nonfeasance and malfeasance at the Prison for Women; and systemic issues of the treatment of women in the correctional setting. The Kingston Report is of exceptional importance for women prisoners, but it also is relevant and useful to the understanding of male imprisonment. Her digests and explications of prison law are extremely helpful.

Justice Arbour has also addressed political discrimination against prisoners. In Sauvé, ${ }^{76}$ she examined the validity of section 51 (e) of the Canada Elections Act, which disqualified prison inmates from voting - a conceded limitation of the Charter-protected right to vote. The Attorney General sought to justify the disqualification under section 1. Justice Arbour rejected the arguments that voting rights should only be recognized for "decent and responsible citizenry" and

75 The Prosecutor y. Jean-Paul Akayesu, ICTR-96-4-T, online: International Criminal Tribunal for Rwanda Homepage $<$ http://www.ictr.org/english/judgements/akayesu.html $>$ paras. 129-131.

76 Sauvé v. Canada (Attorney General) (1992), 7 O.R. (3d) 481 (C.A.), aff'd [1993] 2 S.C.R. 438. 
that the "integrity of the voting process" required the exclusion of prisoners' votes. In her view, the strongest argument supporting the disqualification was that voting rights should be forfeited as punishment. Nevertheless, the legislated voting disqualification was both overinclusive and underinclusive, being based on residence - prison - rather than on conduct. The legislation lumped together all of those who are imprisoned, regardless of the seriousness of their crimes. It did not apply to offenders not serving prison time. Justice Arbour declared section 51(e) invalid.

\section{Institutional Modesty}

Justice Arbour displays a fit institutional modesty in her comments about the criminal law.

She is realistic about deterrent effects of punishment. She understands that the quantum of punishment is but one factor in a deterrence mechanism - and not necessarily even the most important factor. Deterrence "is directly proportional to the perception of the likelihood of being apprehended, tried, convicted and punished. Until the potential offenders have a full appreciation of their exposure to that whole process, I don't think it will have much of a deterrent effect." Punishment, of course, may have some deterrent effects: "it dehabilitates those currently in prison, so they are not out committing other crimes, and it deters those whose criminal mind is sufficiently analytical to consider the risk of exposure in their decision - but I don't think it can eradicate completely the commission of war crimes during times of tremendous turmoil." 78

Justice Arbour has also conveyed a startling, remarkable vision of the criminal law as an expression of shame-not the shame that the offender is to feel as part of his or her atonement, but our shame at our failures, our bit of responsibility for the criminal behaviour of others (although the second last sentence of the quotation suggests that we should not feel too ashamed):

Q: [University of Toronto Faculty Law Review:] Many have charged that the [War Crimes] Tribunal is simply a way for Western nations to address their own guilt for failing to take action before the conflict escalated to such an extreme level $\cdots$

A: Arbour: Let me address the first question, whether we are the by-product of shame. I

\footnotetext{
77 Llewellyn and Raponi, supra note 54 at 93.

78 Ibid.
}

think that the answer is probably yes. But that is what criminal law is all about domestically as well. Each time you bring a rapist or murderer to trial, it is an indictment against our other institutions. It means that our education system failed, our mental health system, our social agencies, and maybe the correctional system - it is usually a history of failure by the time the criminal system gets involved. There is nothing to be particularly startled or ashamed about being a part of this late corrective measure. That is what criminal law is all about. $^{79}$

The criminal law is almost always too late. This realization blocks a certain hubris on the part of justice system actors, and forces critics and members of the public to be coldly realistic about the limited social benefits and changes that can be achieved through the blunt instrument of the criminal law.

\section{Conclusion: A Profile?}

What can we conclude about Justice Arbour, based on her curriculum vitae? Her experience has well prepared her for the country's highest court. In the words of the Toronto Star, "[s] he is a mother, a legal scholar, a teacher and a judge:"80 She knows classrooms, courtrooms, war rooms, and cells. She has walked through circles of hell on earth that most of us would be happiest to avoid. She should have a ready and practical understanding of the wide variety of facts and arguments that will wind their way to the Supreme Court.

What can we conclude about Justice Arbour, based on her record? She is a legal technician, not a bold judicial activist. She is a judge, rather than an advocate or ideologue. She appreciates the legal interests of individuals, groups, and the state. Because she is not an advocate or an ideologue, her decisions are not predictable in the abstract. We can expect her to decide in light of argument, after a full consideration of all of the facts. She is not afraid to make tough calls.

Justice Arbour should be an excellent Supreme Court judge. $\square$

\section{Wayne N. Renke}

Faculty of Law, University of Alberta.

79 Ibid. at 95

80 Editorial, "Judge Arbour" The Toronto Star (11 June 1999), online: The Toronto Star Online <http:/www:thestar.com/back issues...pinion/990611NEW01b_ED-ARBOUR.htm/>. 